\title{
Analysis of Household Hazardous Wastes Awareness Level in Enugu Metropolis
}

\author{
Ubachukwu, N. N. \\ Geography Department, Nigerian Defense Academy, Kaduna, Nigeria \\ nechukwu@yahoo.com
}

Phil-Eze P.O.

Geography Department, University of Nigeria, Nsukka, Enugu State

Emeribe, C. N.

Environmental/Pollution Remediation Unit of the National Centre for Energy and Environment, Energy Commission of Nigeria, University of Benin, Benin City

\section{Doi:10.5901/ajis.2014.v3n1p369}

\section{Abstract}

The study attempts to examine the awareness level household hazardous waste in Enugu metropolis. HHW generated in Enugu Metropolis were classified into eight, they include paints, garden chemicals, batteries, motoring products, medicines, home cleaning products, e-waste and household glasses. Ten layouts were randomly selected out of 41 . A total number of 30 households per Layout were selected, totalling 300 respondents. A total of 24 checklists were used to evaluate the responses of householders to determine their level of awareness of HHW. Analysis of the awareness data was based on the frequency values obtained from our checklists. From our awareness analysis it was found that the level of householders' awareness on the dangers of HHW in the Enugu metropolis is low. This low awareness level on the dangers associated with HHW may largely be attributed to be attitudinal as income level and/ or level of education played little role in the general awareness level. From our PCA we identified four indices which include: general disposal problems, health related issues, environmental problems, and poor handling of HHW, which reflects low awareness of HHW in the study area. There is also no general consensus as to what constitute HHW in the study area as well as their potential health and environmental impacts. This was seen from variations in responses of like-hood impacts of HHW. For example while some respondents agreed that paints may constitute danger to the human health and environment if not properly disposed, other disagree. This development it is anticipated may frustrate any effort at HHW management unless people are sensitized and enlightened.

Keyword: Awareness level; Household hazardous waste, Health and Environment; environmental problem

\section{Introduction}

Municipal wastes represent an important percentage of those produced by the different activities human beings carry on. Studies have found that until a few years ago, the question of domestic products and their wastes did not represent a serious problem for the environment or for humanity's health. However, the introduction of toxic substances or potentially toxic substances into products on the market, the change of consumption habits in today's society, and the increase in urban population has caused an alarming general increase in the production of domestic wastes (Wilson, 1990; Canderio, 1999). In these wastes are various domestic elements which may be classified as contaminants. Most household wastes include among others: household cleaners, materials for home maintenance, garden products, medicines and automotive products. The used contents or leftovers of these products are known as household hazardous wastes. The term 'hazardous wastes' indicates the presence of discarded, unused or leftover portions of hazardous household products which are poisonous, toxic, flammable, caustic, corrosive, reactive, explosive, and radioactive or a combination of these characteristics. Study by Rosas and Gutiérrez (2001) shows that the quantity of HHW's varies from $0.01 \%$ to $1 \%$ of the total solid municipal wastes, depending on the characteristics and customs of each locality. Similarly, Luna (2002) found that $1 \%$ of domestic garbage sampled in his study was consisted of hazardous wastes. Globally, it is estimated that more than 70,000 chemicals are commonly utilized for a wide variety of purposes including production of household products (Connell, Lam Richardson, and Wu, 1999). 
These chemicals so joins the streams of municipal waste, and since these waste is usually not disposed of improperly in most developing country, they pose a threat to sanitation workers and the environment. Household Hazardous Waste (HHW) discarded in the trash may ignite or explode in the collection truck. Trash collectors can be injured from fumes and splashing chemicals. In landfills, leachate from the waste pollutes soil, surface water and groundwater reservoirs. Disposal of HHW in drains can also pollute drinking water. In septic systems, hazardous waste can kill the organisms that make the system work. This may cause bulks of untreated waste to drain into the soil and eventually seep into the groundwater. Sewage treatment plants can be damaged by HHW in the same way as septic systems (Connell, Lam Richardson, and Wu, 1999). Tammenagi (1991) recorded that the environmentally hazardous dumps are unlined, have no leachate control or drainage systems, and the underground water or surface water unmonitored.

In the study area, HHW are usually stored in bins or cartons along with other wastes in individuals' homes and later deposited into public bins placed on the curbside or thrown inside built dumps for collection. The present solid waste disposal method based on mixing of HHW with other household wastes does not only pose problems of disposal but difficulty in monitoring the waste content, or estimating the extent of pollution risks at dumps. In addition, it worrisome to note that open dumping of waste into the nearest open space, either on land or surface water without any environmental consideration continues to be a common practice in the study area. This attitude could explain why there are heaps of wastes at every corner of the environment and the reluctance of municipal waste management staff to clear the waste because of potential injury. There is an increasing worry among environmentalists and Nigerian population that that given the growing population and more sophistication with respect to preferences and appetites for household products, the environmental problems associated with HHW generation and management in Nigerian cities may worsen. Yet, very few studies in the country have been done to examine level of awareness of dangers associated with HHW among the population. This informed the need for the present study.

\section{Research Methodology}

\subsection{Study Area}

The study area is Enugu capital Enugu State. It is located approximately between latitude $60^{\circ} 30^{\prime} \mathrm{N}$ and $6^{\circ} 40^{\prime} \mathrm{N}$ of the equator and longitude $7^{\circ} 20^{\prime} \mathrm{E}$ and $7^{\circ} 35^{\prime} \mathrm{E}$ of the Greenwich meridian. It covers an area of about, 145.8 square kilometers. It is administered by three local authorities namely, Enugu North, Enugu South, and Enugu East local government authorities. Enugu Metropolis is bounded in the north east by Isi-Uzo and northwest by Igbo-Etiti local Government Areas, in the east and south by Nkanu East and Nkanu West L.G.A respectively and in the west by Udi Local Government Area. (Fig.1).

Fig. 1: Map of Enugu Metropolis Showing the Sample Layout

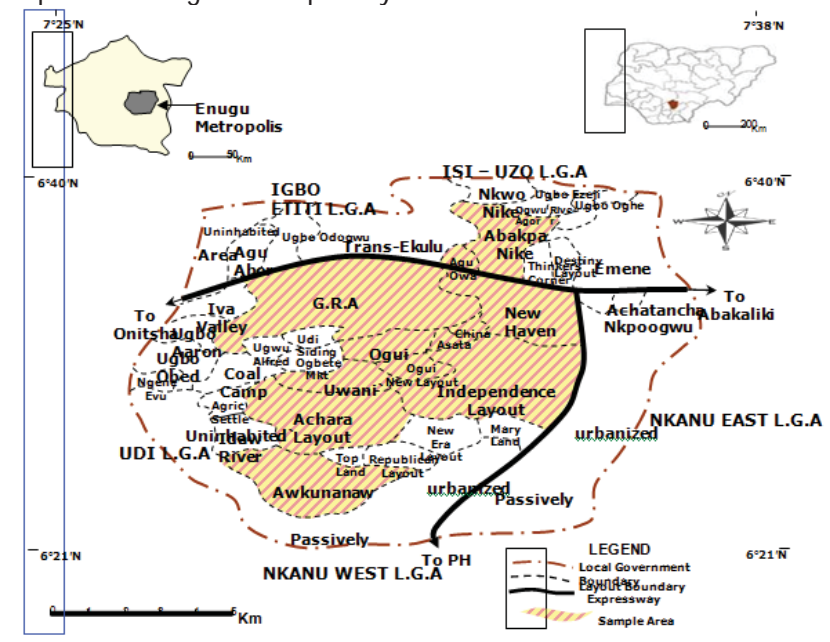

Source: Town Planning Authority, ENUGU, 2009 
The climate of the study area is the tropical wet and dry type according to the Koppen climatic classification system, and experiences two seasons (wet and dry) both which are warm. Rainfall occurrence is high with mean annual totals of $1600 \mathrm{~mm}$. The rainy season generally lasts from April to October, while the dry season lasts from November to March. The topographical features of Enugu Metropolis can be classified into two: to the west is the escarpment which is erosional and is continually eroded backward by the east-flowing rivers and to the east are the Cross River Plains that are generally low and of monotonous relief. Enugu lies at the foot escarpment, of the Cross River Plains, (Mamman, Oyebanji, and Petters 2000). In 2006, the population census figure for Enugu Metropolis was given as 722,665(Federal Republic of Nigeria Official Gazette, 2007).

\subsection{Site selection}

The study area is demarcated into 41 residential layouts for administrative reason, but for the purpose of this work, 10 Layouts were randomly selected. The criteria for selection of these layouts were to include typologies of layouts, and the diversity of households among the selected layouts. These layouts include, Abakpa, Achara, Asata, Awkunanaw, G.R.A., Independence layout, Iva-Valley, New Haven, Ogui, and Uwani (Fig.1). The sampling framework for this study was 300 households comprising 30 households from each of the10 wards named above.

\subsection{Data Collection}

The study is largely quantitative and utilized data collected through household questionnaire survey. Questionnaire was administered for the purpose of exploring level of awareness of HHW on health, environment and disposal in Enugu Metropolis were analyzed. A number of questions were asked about perception of HHW issues. Householders were asked about their understanding of the impacts of household products covered by the survey on their own health when in use, the harm it might cause to the environment, and if they are a problem when disposed of. The checklist was administered to three hundred inhabitants in ten layouts spatially segregated and randomly selected in Enugu metropolis. Thirty households were selected for the study in each layout, a total of 300 householders responded. The data were collected between August and September 2010.

A total of 24, (twenty-four) checklist were used to evaluate the responses of householders to determine their level of awareness of HHW in Enugu Metropolis. Analysis of the awareness data was based on the frequency values obtained from our checklists. This enabled us to obtain the mean scores, standard deviation and variance of the frequency counts of the response values whose sum total is 15 for each variable. There are 24 variables which were assessed on the Likert five point response continuum scales. The Strongly Agree was rated 5, Agree 4, Undecided 3, Disagree 2, and Strongly Disagree 1. Adding all the ratings together gave us a total of 15 points. In our interpretation, any mean above 3.5 indicates that they agree, and they are aware. Mean below 3 implies that they disagree and the level of awareness is low and exactly 3 or between 2.5 and 3.4 shows a moderate level of awareness. Thus, each of the variables was assessed to determine the degree of the level of public awareness of HHW in Enugu Metropolis.

Interview was carried out with Municipal Solid Waste Management officials to provide information of the institutional framework for HHW management, officials' attitude and efforts at HHW collection and management in Enugu Metropolis. The Enugu State Sanitary landfill site (ENSEPA) was visited and workers in the site were interviewed, and pictures were taken at the site.

\subsection{Data Analysis}

The data were analyzed using descriptive and simple statistical analysis i.e. percentages, pie charts and bar graphs were used to relate the factors affecting HHW generation and also the magnitude of generation of HHW. The checklists method were used and coded with Likert five point response continuum scales with total of 24 structured questions to evaluate the level of awareness of HHW for this study. Principal component analysis (PCA) was use to extract the major underlying components that determine the level of HHW awareness in the study area. 


\section{Results and Discussion}

\subsection{Awareness of Household Hazardous Waste on Usage, Health, and Disposal Issues}

The statistical frequency of the awareness level of HHW is shown in Table 1. The interpretation of the obtained results here reflects the perception of the householders on how HHW is a danger to health, environment and disposal problem.

Table 1: Absolute and Relative Frequency Distribution of Reponses on the Level of Public Awareness of HHW in Enugu Metropolis.

\begin{tabular}{|c|c|c|c|c|c|c|c|c|c|c|}
\hline & & 5 & 4 & 3 & 2 & 1 & & & & \\
\hline code & Variable & 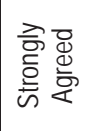 & $\begin{array}{l}\overline{8} \\
\overline{0} \\
\overline{8}\end{array}$ & $\begin{array}{l}\overline{0} \\
\frac{0}{0} \\
\frac{0}{0} \\
\frac{1}{5}\end{array}$ & $\begin{array}{l}\mathscr{E} \\
\frac{8}{8} \\
\square \\
\square\end{array}$ & 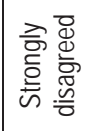 & 覀 & 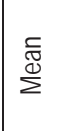 & 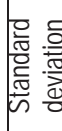 & 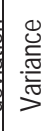 \\
\hline A1 & Paints can be harmful to health if not used properly & $\begin{array}{c}57 \\
19 \% \\
\end{array}$ & $\begin{array}{c}93 \\
31 \% \\
\end{array}$ & \begin{tabular}{|c|}
40 \\
$13.3 \%$ \\
\end{tabular} & $\begin{array}{c}73 \\
24.3 \% \\
\end{array}$ & $\begin{array}{c}37 \\
12.3 \% \\
\end{array}$ & 300 & 3.2 & 1.0 & 1.0 \\
\hline A2 & Paints can be harmful to the environment & $\begin{array}{c}57 \\
19 \% \\
\end{array}$ & $\begin{array}{c}93 \\
31 \%\end{array}$ & \begin{tabular}{|c|}
40 \\
$13.3 \%$ \\
\end{tabular} & $\begin{array}{c}73 \\
24.3 \% \\
\end{array}$ & $\begin{array}{c}37 \\
12.3 \% \\
\end{array}$ & 300 & 3.2 & 1.0 & 1.0 \\
\hline A3 & Paints can be a problem to dispose of & $\begin{array}{c}57 \\
19 \% \\
\end{array}$ & $\begin{array}{c}93 \\
31 \%\end{array}$ & \begin{tabular}{|c|}
40 \\
$13.3 \%$ \\
\end{tabular} & $\begin{array}{c}37 \\
12.3 \% \\
\end{array}$ & $\begin{array}{c}73 \\
24.3 \% \\
\end{array}$ & 300 & 3.1 & 1.0 & 1.0 \\
\hline B1 & Garden chemicals can be harmful to health & \begin{tabular}{|c|}
31 \\
$10.3 \%$ \\
\end{tabular} & $\begin{array}{c}119 \\
39.7 \% \\
\end{array}$ & \begin{tabular}{|c|}
65 \\
$21.7 \%$ \\
\end{tabular} & $\begin{array}{c}66 \\
22 \% \\
\end{array}$ & \begin{tabular}{|c|}
19 \\
$6.3 \%$ \\
\end{tabular} & 300 & 3.3 & 1.0 & 0.9 \\
\hline B2 & Garden chemicals can be Harmful to the environment & $\begin{array}{c}87 \\
29 \% \\
\end{array}$ & $\begin{array}{c}96 \\
32 \% \\
\end{array}$ & \begin{tabular}{|c|}
63 \\
$21 \%$ \\
\end{tabular} & $\begin{array}{c}40 \\
13.3 \% \\
\end{array}$ & $\begin{array}{c}14 \\
4.7 \% \\
\end{array}$ & 300 & 3.8 & 1.0 & 0.9 \\
\hline B3 & $\begin{array}{l}\text { Garden chemicals can cause problem when disposed } \\
\text { of }\end{array}$ & $\begin{array}{c}81 \\
27 \% \\
\end{array}$ & $\begin{array}{l}102 \\
34 \% \\
\end{array}$ & $\begin{array}{c}36 \\
12 \% \\
\end{array}$ & $\begin{array}{l}18 \\
6 \% \\
\end{array}$ & $\begin{array}{c}63 \\
21 \% \\
\end{array}$ & 300 & 3.4 & 1.0 & 0.9 \\
\hline $\mathrm{C} 1$ & $\begin{array}{l}\text { Motoring Products can be harmful to health if not used } \\
\text { properly }\end{array}$ & $\begin{array}{c}22 \\
7.3 \% \\
\end{array}$ & $\begin{array}{c}28 \\
9.3 \% \\
\end{array}$ & \begin{tabular}{|c|}
50 \\
$16.7 \%$ \\
\end{tabular} & $\begin{array}{l}114 \\
38 \% \\
\end{array}$ & $\begin{array}{c}86 \\
28.7 \% \\
\end{array}$ & 300 & 2.3 & 0.9 & 0.9 \\
\hline $\mathrm{C} 2$ & Motoring Products can be harmful to the environment & $\begin{array}{c}22 \\
7.3 \% \\
\end{array}$ & $\begin{array}{l}18 \\
6 \% \\
\end{array}$ & \begin{tabular}{|c|}
80 \\
26.7 \\
\end{tabular} & $\begin{array}{c}114 \\
38 \% \\
\end{array}$ & $\begin{array}{c}66 \\
22 \% \\
\end{array}$ & 300 & 2.4 & 0.9 & 0.9 \\
\hline C3 & Motoring Products can be a problem to dispose of & $\begin{array}{c}22 \\
7.3 \% \\
\end{array}$ & $\begin{array}{l}18 \\
6 \% \\
\end{array}$ & $\begin{array}{c}66 \\
22 \% \\
\end{array}$ & $\begin{array}{c}80 \\
26.7 \% \\
\end{array}$ & $\begin{array}{l}114 \\
38 \% \\
\end{array}$ & 300 & 2.2 & 0.9 & 0.9 \\
\hline D1 & $\begin{array}{l}\text { Household Batteries can be harmful to health if not } \\
\text { used properly }\end{array}$ & $\begin{array}{l}15 \\
5 \% \\
\end{array}$ & $\begin{array}{c}65 \\
21.7 \% \\
\end{array}$ & \begin{tabular}{|c|}
80 \\
$26.7 \%$ \\
\end{tabular} & $\begin{array}{c}107 \\
35.7 \% \\
\end{array}$ & $\begin{array}{c}33 \\
11 \% \\
\end{array}$ & 300 & 2.7 & 1.0 & 0.9 \\
\hline D2 & $\begin{array}{l}\text { Household Batteries can be harmful to the } \\
\text { environment }\end{array}$ & $\begin{array}{l}15 \\
5 \%\end{array}$ & $\begin{array}{c}65 \\
21.7 \% \\
\end{array}$ & \begin{tabular}{|c|}
80 \\
$26.7 \%$ \\
\end{tabular} & $\begin{array}{c}107 \\
35.7 \% \\
\end{array}$ & $\begin{array}{c}33 \\
11 \%\end{array}$ & 300 & 2.7 & 1.0 & 0.9 \\
\hline D3 & Household Batteries can be a problem to dispose of & $\begin{array}{l}15 \\
5 \% \\
\end{array}$ & $\begin{array}{c}65 \\
21.7 \% \\
\end{array}$ & \begin{tabular}{c|c|}
80 \\
$26.7 \%$ \\
\end{tabular} & $\begin{array}{c}107 \\
35.7 \% \\
\end{array}$ & $\begin{array}{c}33 \\
11 \% \\
\end{array}$ & 300 & 2.7 & 1.0 & 0.9 \\
\hline E1 & E-waste can be harmful to health if not used properly & $\begin{array}{c}22 \\
7.3 \% \\
\end{array}$ & $\begin{array}{c}78 \\
26 \% \\
\end{array}$ & \begin{tabular}{|l|}
120 \\
$40 \%$ \\
\end{tabular} & $\begin{array}{c}50 \\
16.7 \% \\
\end{array}$ & $\begin{array}{c}30 \\
10 \%\end{array}$ & 300 & 3.0 & 1.0 & 0.9 \\
\hline E2 & E-waste can be harmful to the environment & \begin{tabular}{|c|}
62 \\
$20.7 \%$ \\
\end{tabular} & $\begin{array}{c}73 \\
24.3 \% \\
\end{array}$ & $\begin{array}{c}45 \\
15 \% \\
\end{array}$ & $\begin{array}{l}24 \\
8 \% \\
\end{array}$ & $\begin{array}{c}96 \\
32 \% \\
\end{array}$ & 300 & 2.9 & 0.9 & 1.0 \\
\hline E3 & E-waste can be a problem to dispose of & \begin{tabular}{|c|}
62 \\
$20.7 \%$ \\
\end{tabular} & $\begin{array}{c}73 \\
24.3 \% \\
\end{array}$ & $\begin{array}{c}45 \\
15 \% \\
\end{array}$ & $\begin{array}{l}24 \\
8 \%\end{array}$ & $\begin{array}{c}96 \\
32 \% \\
\end{array}$ & 300 & 2.9 & 0.9 & 1.0 \\
\hline F1 & $\begin{array}{l}\text { Medicines can be harmful to } \\
\text { health if not used properly }\end{array}$ & $\begin{array}{c}22 \\
7.3 \% \\
\end{array}$ & $\begin{array}{c}78 \\
26 \% \\
\end{array}$ & $\begin{array}{l}12 \\
4 \% \\
\end{array}$ & $\begin{array}{c}88 \\
29.4 \% \\
\end{array}$ & $\begin{array}{c}100 \\
33.3 \% \\
\end{array}$ & 300 & 2.6 & 0.9 & 0.9 \\
\hline F2 & Medical waste can be harmful to the environment & $\begin{array}{c}54 \\
18 \% \\
\end{array}$ & $\begin{array}{c}76 \\
25.3 \% \\
\end{array}$ & $\begin{array}{c}45 \\
15 \% \\
\end{array}$ & $\begin{array}{c}25 \\
8.3 \% \\
\end{array}$ & $\begin{array}{c}100 \\
33.3 \% \\
\end{array}$ & 300 & 2.0 & 0.7 & 0.7 \\
\hline F3 & Medical waste can be a problem to dispose of & $\begin{array}{c}54 \\
18 \% \\
\end{array}$ & $\begin{array}{c}76 \\
25.3 \% \\
\end{array}$ & $\begin{array}{c}45 \\
15 \% \\
\end{array}$ & $\begin{array}{c}25 \\
8.3 \% \\
\end{array}$ & $\begin{array}{c}100 \\
33.3 \% \\
\end{array}$ & 300 & 2.0 & 0.7 & 0.7 \\
\hline G1 & $\begin{array}{l}\text { Home-cleaning products can be harmful to health if } \\
\text { not properly used }\end{array}$ & $\begin{array}{c}20 \\
6.7 \% \\
\end{array}$ & $\begin{array}{c}83 \\
27.7 \% \\
\end{array}$ & \begin{tabular}{|c|}
47 \\
$15.7 \%$ \\
\end{tabular} & $\begin{array}{c}40 \\
13.3 \% \\
\end{array}$ & $\begin{array}{c}110 \\
36.7 \% \\
\end{array}$ & 300 & 2.5 & 0.9 & 0.9 \\
\hline $\mathrm{G} 2$ & $\begin{array}{l}\text { Home-cleaning products can be harmful to the } \\
\text { environment }\end{array}$ & $\begin{array}{c}41 \\
13.7 \% \\
\end{array}$ & $\begin{array}{c}94 \\
31.3 \% \\
\end{array}$ & \begin{tabular}{|c|}
45 \\
$15 \%$ \\
\end{tabular} & $\begin{array}{c}45 \\
15 \% \\
\end{array}$ & $\begin{array}{c}75 \\
25 \% \\
\end{array}$ & 300 & 3.4 & 1.2 & 1.1 \\
\hline G3 & $\begin{array}{l}\text { Home-cleaning products can be a problem to dispose } \\
\text { of }\end{array}$ & $\begin{array}{c}15 \\
5 \%\end{array}$ & $\begin{array}{c}65 \\
21.7 \% \\
\end{array}$ & \begin{tabular}{|c|}
80 \\
$26.7 \%$
\end{tabular} & $\begin{array}{c}107 \\
35.7 \%\end{array}$ & $\begin{array}{c}33 \\
11 \% \\
\end{array}$ & 300 & 2.7 & 0.9 & 0.9 \\
\hline
\end{tabular}




\begin{tabular}{|c|c|c|c|c|c|c|c|c|c|c|}
\hline $\mathrm{H} 1$ & Glasses can be harmful to health if not used properly & $\begin{array}{c}75 \\
25 \%\end{array}$ & $\begin{array}{c}100 \\
33.3 \%\end{array}$ & $\begin{array}{c}32 \\
10.7 \%\end{array}$ & $\begin{array}{c}75 \\
25 \%\end{array}$ & $\begin{array}{l}18 \\
6 \%\end{array}$ & 300 & 2.9 & 0.8 & 0.7 \\
\hline $\mathrm{H} 2$ & Glasses can be harmful to the environment & $\begin{array}{c}31 \\
10.3 \%\end{array}$ & $\begin{array}{c}119 \\
39.7 \%\end{array}$ & $\begin{array}{c}66 \\
22 \%\end{array}$ & $\begin{array}{c}19 \\
6.3 \%\end{array}$ & $\begin{array}{c}65 \\
21.7 \%\end{array}$ & 300 & 3.1 & 1.0 & 0.9 \\
\hline H3 & Glasses can be a problem to dispose of & $\begin{array}{c}15 \\
5 \%\end{array}$ & $\begin{array}{c}65 \\
21.7 \%\end{array}$ & $\begin{array}{c}80 \\
26.7 \%\end{array}$ & $\begin{array}{c}107 \\
35.7 \%\end{array}$ & $\begin{array}{c}33 \\
11 \%\end{array}$ & 300 & 3.0 & 1.0 & 0.9 \\
\hline
\end{tabular}

Source: Field work 2010

From Table, variable A1 (Paints and their related products can be harmful to the health if not used properly) and variable A2 (Paints and their related products can be harmful to the environment), both scored $31 \%$ under the Agreed column, $24.3 \%$ for Disagree, while $19 \%$ and $13.3 \%$ for strongly agree and undecided respectively, strongly disagree scored $12.3 \%$. Although $50 \%$ majority of the respondents agree they are aware that these variables can be a problem to health (e.g. irritate skin, eyes), and environment (e.g. pollution of water), $36.6 \%$ of the respondents are not aware and $13.3 \%$ were indeed uncertain and unwilling to express an opinion on these variables. With a mean of 3.2 a standard deviation and variance of 1.0, we concluded that the level of awareness for variable A1 and A2 is moderate in the study area.

Variable A3 (Paints and their related products can be a problem to dispose of) the perception of the people again was moderate. Our analysis returned a mean score of 3.1, standard deviation and variance of 1.0. This is because the highest score of 31\% for Agree, 24.3\% of strongly Disagree, 19\% on Strongly Agree and 13.3\% for Undecided and 12.3 $\%$ for Disagree respectively. $50 \%$ of respondents were aware of problems in disposal (for example to collection workers, leakage on roads and contamination of recyclables) $32.2 \%$ were unaware and $12.3 \%$ were indecisive.

Variable B1 (Garden chemicals can be harmful to health if not used properly), scored $39.7 \%$ for Agree, $22 \%$ of Disagree, $21.7 \%$ was registered for Undecided. The score of other categories are very low ranging from $10.3 \%$ for Strongly Agree and 6.3\% for Strongly Disagree.50\% of the respondents agree they are aware, (these variable can be a harmful in use when you do not follow the instructions. It can cause harm to pets children, skin irritants etc), $28 \%$ were unaware and $21.7 \%$ were indecisive. The variable scored a mean of 3.3, standard deviation of 1.0 and variance of 0.9 to show that the level of HHW is moderate.

Variable B2 (Garden chemicals can be harmful to the environment) scored 32\% on Agree, 29\% on Strongly Agree; $21 \%$ for Undecided; $13.3 \%$ for Disagree; and $4.7 \%$ for strongly Disagree. $61 \%$ of the respondents agree that this variable can be harmful to the environment. There is a strong consensus that the level of public awareness of variable B2 is high because of the mean of 3.8, standard deviation of 1.0 and variance of 0.9. The householders in Enugu Metropolis are aware that garden chemicals can be harmful to the environment.

Variable B3 (Garden chemicals can cause a problem when disposed off), recorded 34\% for Agree; 21\% for Strongly Disagree; $27 \%$ for Strongly Agree; $12 \%$ under Undecided; $6 \%$ for Disagree. With a mean of 4, standard deviation 1.0 and variance 0.9 , the people again were aware of the dangers of improper disposal of garden chemicals (eg they cause liquid mess in dust bin). Therefore, the level of awareness of this variable is high.

Variable C1(Motoring products can be harmful to health if not used properly ), scored 38\% for Disagree; $28.7 \%$ for Strongly Disagree; $16.7 \%$ on Undecided; $9.3 \%$ on Agree, and $7.3 \%$ for Strongly Agree. There is a strong consensus that $66.7 \%$ of respondents are unaware of threats this variable can be to their health (they are toxic and some products are skin irritants), with a mean of 2.3, and standard deviation and variance of 0.9 . This implies that the level of public awareness of this variable is very low.

Variable C2 (Motoring products can be harmful to the environment), the householders disagree with the dangers of this HHW and this implies that their level of awareness is low. Our analysis returned a mean score of 2.4, standard deviation and variance of 0.9 . This was because the highest score of $60 \%$ was recorded for Disagree, $22 \%$ for Undecided, and $13.3 \%$ for Agree.

Variable C3 (Motoring products can be a problem to dispose off), recorded scores of $38 \%$ and $26.7 \%$ under the Disagree and Strongly Disagree column. 22\% for Undecided, 7.3\% and 6\% for Strongly Agree and Agree respectively. A total of $65.7 \%$ of responded to disagree, and with a mean of 2.2, Standard deviation and variance of 0.9 . We can conclude that the level of awareness of the dangers of these variables to the public is low.

Variables D1 (Household batteries can be harmful to health), D2 (household batteries can be harmful to the environment), and D3 (household batteries can be a problem to dispose off), all scored $35.7 \%$ for Disagree; $26.7 \%$ for Undecided; $21.7 \%$ for Agree; $11 \%$ for Strongly Disagree, and 5\% for Strongly Agree. A high number of respondent 46.7\% disagree with these variables. With a mean score of 2.7, and standard deviation of 1.0 and variance of 0.9 , it implies that people are unaware of the dangers of these variables. 
Variable E1 (E-waste can he harmful to health if not used properly), recorded scores of $40 \%$ for Undecided; $26 \%$ for Agree; $16.7 \%$ on Disagree; $10 \%$ for Strongly Disagree; and $7.3 \%$ on Strongly Agree positive. $40 \%$ of the respondents were indecisive, $33.3 \%$ are aware and $26.7 \%$ are not aware of this variable. With a mean score of 3.0 , standard deviation of 1.0, and variance of 0.9 , this implies that the public are indifferent to the dangers of variable E1.

Variable E2 (E-waste can be harmful to the environment if not used properly) and E3 (E-waste can be a problem to dispose off ) both scored 32\% for Strongly Disagree; $24.3 \%$ for Agree; $20.7 \%$ for Strongly Agree; $15 \%$ for Undecided; and $8 \%$ for Disagree. A mean of 2.9, standard deviation 0.9 and variance 1.0 was recorded. $45 \%$ agree, and are aware; $40 \%$ disagree and are unaware and $15 \%$ were indecisive. The response of the public is so diverse but indicates there is a moderate level of awareness of these variables.

Variable F1(Medicine can be harmful to health if not properly used), scored $33.3 \%$ on Strongly Disagree, while Strongly Disagree scored $29.4 \%$, to show a low level of awareness. However, a score of $26 \%$ was recorded for Agree, and $7.3 \%$ and $4 \%$ for Strongly Agree and Undecided respectively. $66.7 \%$ of the respondents are unaware of the dangers of this variable to their health. With a mean of 2.6 , and standard deviation and variance 0.9 , this shows that the level of awareness of this variable is low.

Variables F2 (Medical waste can be harmful to the environment) and F3 (Medical waste can be a problem to dispose off) both scored the same. The response of the people was so low so the level of awareness of these variables is low. This is because our analysis returned a mean score of 2.0, which implies that the people disagree. The highest score of $41 \%$ was recorded for agree, $43.3 \%$ for disagree and $15 \%$ were indecisive. Their low responses have slight edge over the high responses, a situation that the people could not readily perceive the dangers of these variables to the environment and disposal.

Variable G1(Home cleaning products can be harmful to health if not used properly) scored $36.7 \%$ on Strongly Disagree, $27.7 \%$ for Agree; $15.7 \%$ Undecided; $13.3 \%$ on Disagree; $6.7 \%$ on Strongly Agree. $50 \%$ of the respondent ticked disagree; $34.1 \%$ agree; $15.7 \%$ undecided. With a mean of 2.5, standard deviation, and variance of 0.9 . The interpretation is that the awareness of the dangers of this variable on health is low.

Variable G2(Home cleaning products can be harmful to the environment), scored high on Agree; $39.7 \%$ and $33.3 \%$ on Strongly Disagree; $15 \%$ Undecided and Disagree, and $15 \%$ on Strongly Agree. $53.4 \%$ of the responded ticked that they are aware of the effect of these variables to health. A mean of 3.4 on our 5-point scale of estimation is not significantly observed which implies that the level of awareness of the variable is moderate.

Variable G3 (Home cleaning products can be a problem to dispose off), recorded scores of $35.7 \%$ on Disagree column; $26.7 \%$ on Undecided; $21.7 \%$ on Agree; $11 \%$ on Strongly Disagree and, 5\% Strongly Agree respectively. 46.7\% of the respondents are aware of the effects of these variable during disposal. With a mean score of 2.7, standard deviation and variance 0.9 , shows the variable $\mathrm{G} 3$ is not significantly responded to, so its public level of awareness is moderately low.

Variable $\mathrm{H} 1$ (Household glasses can be harmful to health) scored $33.3 \%$ on Agree; $25 \%$ on Strongly Agree and Disagree column, $10 \%$ on Undecided, and $6 \%$ on Strongly Disagree. $58.3 \%$ of respondents are aware of the effects this variable have to their health if not used properly. A mean score of 2.9 , standard deviation of 0.8 , and variance of 0.7 , implies a low level of awareness of the variable.

Variable $\mathrm{H} 2$ (Household glasses can be harmful to your environment) recorded scores of 39.7\% under Agree; $22 \%$ under Undecided, $21.7 \%$ on Strongly Disagree, $10.3 \%$ on Strongly Agree, and 6.3\% on Disagree. $48 \%$ of the sampled householders are aware of the effect of these variables to the environment. With a mean of 3.1, it shows that the public were indeterminate. The level of awareness is moderate.

Variable $\mathrm{H} 3$ (Household glasses can be a problem to dispose off) scored $35.7 \%$ on Disagree, $26.7 \%$ on Undecided; $21.7 \%$ on Agree; $11 \%$ Strongly Disagree; $5 \%$ Strongly Agree. $46.7 \%$ are unaware that these variables can be a problem to dispose of. A mean score of 3.0 , standard deviation of 1.0 and variance of 0.9 , shows that the response was indeterminate and the level of awareness is moderate.

Variables A1-H3 are represented on a Bar chart as shown in Fig 1 (A-H have been defined previously). The variables were plotted against their means. 


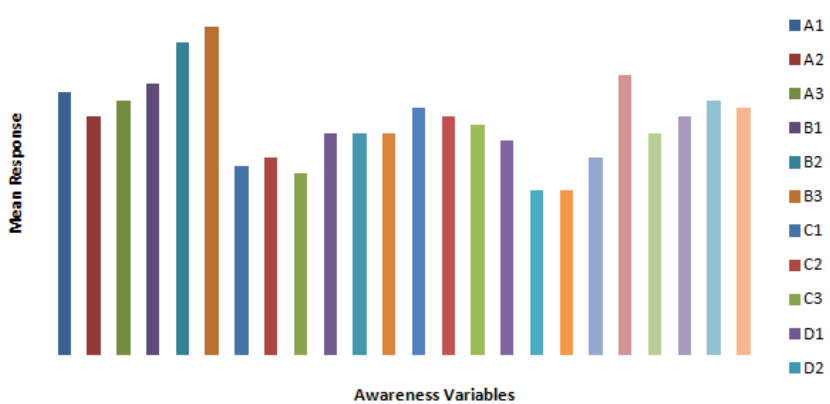

Fig 1 shows that with exceptions of B2 and B3which the public agreed to, C1, C2, C3, F2 and F3 which the public disagreed to, the other 18 variables the public were undecided or indecisive. Therefore there is a strong consensus that the level of HHW awareness in Enugu Metropolis is low.

\subsection{Factor Analysis of Awareness level of HHW in Enugu Metropolis}

We adopted the PCA model to identify important factors which could be employed to explain the underlying factors responsible for the low level of awareness of HHW in Enugu Metropolis. The model successfully transformed our 24 attributes to 4 underlying dimensions which are shown in the order of importance (Table 3). The varimax orthogonal rotation was utilized to maximize variances and place the component axes in a unique position such that the components can be interpreted by as large a loading as possible relating to the fewer attributes possible. From Table 2, it is observable that Component I explains $33.182 \%$ of the total variance in the attributes, while Component IV, with a percentage of $17.218 \%$, explains the least. Thus, the 4 components explain $100 \%$ of the total variance.

Table 2: PCA of the attributes of awareness of household hazardous waste.

\begin{tabular}{|c|c|c|c|c|c|}
\hline \multirow[t]{2}{*}{ Code } & & \multicolumn{4}{|c|}{ Components } \\
\hline & Attributes of level of awareness of $\mathrm{HHW}$ & 1 & II & III & IV \\
\hline $\mathrm{X} 1$ & Paints can be harmful to health if not used properly & .255 & $.955^{*}$ & .089 & .120 \\
\hline $\mathrm{X} 2$ & Paints can be harmful to the environment & .104 & -.321 & $.936^{*}$ & -.198 \\
\hline X3 & Paints can be a problem to dispose of & -.228 & $.979^{\star}$ & .304 & -.009 \\
\hline $\mathrm{X} 4$ & Garden chemicals can be harmful to health & .537 & .673 & .426 & -.277 \\
\hline $\mathrm{X} 5$ & Garden chemicals can be Harmful to the environment & -.131 & .692 & .004 & -.710 \\
\hline $\mathrm{X} 6$ & Garden chemicals can cause problem when disposed of & $.985^{*}$ & .475 & .528 & -.251 \\
\hline $\mathrm{X} 7$ & Motoring Products can be harmful to health if not used properly & .458 & $.926^{*}$ & -.195 & .492 \\
\hline $\mathrm{X} 8$ & Motoring Products can be harmful to the environment & .630 & -.462 & -.385 & $.990^{*}$ \\
\hline $\mathrm{X9}$ & Motoring Products can be a problem to dispose of & .222 & -.749 & .066 & -.621 \\
\hline $\mathrm{X} 10$ & Batteries can be harmful to health if not used properly & .550 & .131 & -.087 & .082 \\
\hline $\mathrm{X} 11$ & Batteries can be harmful to the environment & -658 & .117 & $.972^{\star}$ & .102 \\
\hline $\mathrm{X} 12$ & Batteries can be a problem to dispose of & $.965^{*}$ & .136 & -.213 & .076 \\
\hline $\mathrm{X} 13$ & E-waste can be harmful to health if not used properly & .704 & -.142 & .301 & -.628 \\
\hline X14 & E-waste can be harmful to the environment & -.698 & .193 & $.979^{\star}$ & .120 \\
\hline $\mathrm{X} 15$ & E-waste can be a problem to dispose of & $.984^{*}$ & .694 & .464 & .022 \\
\hline $\mathrm{X} 16$ & Medicines can be harmful to health if not used properly & .065 & .145 & .387 & $.909^{*}$ \\
\hline $\mathrm{X} 17$ & Medical waste can be harmful to the environment & -.081 & -.209 & $.964 *$ & .187 \\
\hline $\mathrm{X} 18$ & Medical waste can be a problem to dispose of & $.989^{\star}$ & -.572 & .356 & .422 \\
\hline $\mathrm{X} 19$ & Home-cleaning products can be harmful to health if not properly used & -.196 & -.239 & .422 & $.937^{*}$ \\
\hline $\mathrm{X} 20$ & Home-cleaning products can be harmful to the environment & .029 & .305 & $.925^{*}$ & .199 \\
\hline $\mathrm{X} 21$ & Home-cleaning products can be a problem to dispose of & $.989 \%$ & .056 & .004 & .140 \\
\hline $\mathrm{X} 22$ & Glasses can be harmful to health if not used properly & .047 & $.991^{*}$ & -.084 & -.988 \\
\hline $\mathrm{X} 23$ & Glasses can be harmful to the environment & .021 & .229 & $.926 *$ & -.298 \\
\hline $\mathrm{X} 24$ & Glasses can be a problem to dispose of & $.959^{*}$ & .066 & -.249 & .012 \\
\hline
\end{tabular}




\begin{tabular}{|c|c|c|c|c|c|}
\hline Eigen values & 7.964 & 6.044 & 5.860 & 4.132 \\
\hline \%of explained variance & & 33.182 & 25.182 & 24.417 & 17.218 \\
\hline Cumulative \% variance & & 33.182 & 58.365 & 82.782 & 100.00 \\
\hline
\end{tabular}

" significant loadings exceeding +/_0.9, at 95\% confidence level.

\subsubsection{Component I}

Component I has an eigen value of 7.964 and explains $33.182 \%$ of the total variance. High positive loadings are found on 6 attributes namely X6 (Garden chemicals can cause a problem when disposed of), X12 (batteries can be a problem to dispose of), X15(E-waste can be a problem to dispose of), X18(Medical waste can be a problem to dispose of), X21(Home cleaning products can be a problem to dispose of), X24 (Household glasses can be a problem to dispose of). These attributes are describing the general disposal problem of HHW arising from poor awareness of the harmful effects of HHW. Consequently many people are exposed to the dangers of improper disposal of HHW in Enugu metropolis. Component I is identified as general disposal problems.

\subsubsection{Component II}

Component II has an eigen value of 6.044 and explains $25.182 \%$ of the total variance. Three attributes have high positive loadings which are X1(Paints and their related products can be harmful to the health if not used properly), X3 (Paints can be a problem to dispose of) X7(Motoring Products can be harmful to health if not used properly), X22(Household glasses can be harmful to health). It is identified as poor handling of HHW associated especially with paints, used motoring products and glasses. The component II is therefore, identified as poor handling of $\mathrm{HHW}$.

\subsubsection{Component III}

Component III has an eigen value of 5.860 and accounts for $24.417 \%$ of the total explained variance. Also this component has high positive loadings on five attributes. X2(Paints can be harmful to the environment), X11(Batteries can be harmful to the environment), X14(E-waste can be harmful to the environment), X17(Medical waste can be harmful to the environment), X20 (Home cleaning products can be harmful to the environment), X23(glasses can be harmful to the environment). This component is thus, an index of the environmental problems caused by HHW. This indicator reflects that householders are not aware of the dangers of HHW to their environment. It is identified as environment hazards.

\subsubsection{Component IV}

Component IV has an eigen value of 4.132 and explains $17.218 \%$ of the total variance. It has high positive loadings on four attributes. X8(Motoring Products can be harmful to the environment), X16(Medicine can be harmful to health if not properly used), X19 (Home-cleaning products can be harmful to health if not properly used), X22(Glasses can be harmful to health if not used properly). It is identified as the dangers of HHW to health.

Table 3: The relative strength of the underlying dimension of the attributes that determine the level of awareness of HHW in Enugu Metropolis.

\begin{tabular}{cclcc}
\hline S/N & Components & Underlying Dimensions & Relative Contribution & Cumulative \\
\hline $\mathbf{1}$ & I & Disposal problems & 33.182 & 33.182 \\
$\mathbf{2}$ & II & Poor Handling & 25.182 & 58.365 \\
$\mathbf{3}$ & III & Environmental Hazards & 24.417 & 82.782 \\
$\mathbf{4}$ & IV & Health Problem & 17.218 & 100.00 \\
\hline
\end{tabular}

\section{Conclusion and Recommendations}

The HHW generated in Enugu Metropolis were classified into eight, they include paints, garden chemicals, batteries, motoring products, medicines, home cleaning products, e-waste and household glasses. From our awareness analysis it was found that the level of householders' awareness on the dangers of HHW in the Enugu metropolis is low. This low awareness level on the dangers associated with HHW may largely be attributed to be attitudinal as income level and/ or 
level of education played little role in the general awareness level. From our PCA we identified four indices which include: general disposal problems, health related issues, environmental problems, and poor handling of HHW, which reflects low awareness of HHW in the study area. There is also no general consensus as to what constitute HHW in the study area as well as the potential health and environmental impacts which HHW hold. This resulted from variations in responses of like-hood impacts of HHW. For example while some respondents agreed that paints may constitute danger to the human health and environment if not properly disposed, other disagree. This development it is anticipated may likely to frustrate any effort at HHW management unless people are sensitized and enlightened.

During the field study it was observed that only the state solid waste management agency Enugu State Waste Management Agency ESWAMA manages domestic waste from households and there is no provision for HHW management. In addition, it was observed that at the moment there is no HHW collection taking place in Enugu Metropolis. From our awareness analysis, the people have a low level of awareness of the dangers of HHW to their health, environment and improper disposal. Thus for an effective management of HHW in Enugu Metropolis, we suggest the creation of laws or legislations backing the management of HHW in the study area. In addition, there should be a creation of a unit under ESWAMA solely for the management of HHW in Enugu Metropolis. This unit will be in charge of awareness campaigns on HHW. They will provide facilities for the collection, disposal and recycling of HHW in Enugu Metropolis. Also, this unit under ESWAMA should provide facilities for proper disposal of HHW. Since HHW are not separated from other wastes, it is necessary for it to provide a separate bag for HHW and distribute them to homes to ease and promote sorting.

\section{References}

Candelario Mejía Gerardo (1999) Los desechos domésticos contaminantes: generación, disposición, impacto y alternativas de solución en la zona metropolitana de Guadalajara basadaen la educación ambiental

Connell, D., Lam, P., Richardson, B. and Wu, R. (1999): "Introduction to Ecotoxicology". Blackwell Science Limited, United Kingdom, 1999

Egboka, B.C.E.(1985): Water Resources Problems in Enugu Area. In Process of the Literature, Symponsis on Scientific basis of water Resources Management. Jerusalem (Isreal). Pp95-106

Ejlertssson, J., Karlsson, A., Lagerkvist, A., Hjertberg, T.A. and Suensson, B.(2007): "Effects of Co-disposal of Waste Containing Orgranic Pollutants with Municipal Solid Waste - a Landfill. Simulation reactor study". Advance in Environmental Research 7. Pp 949-960.Scopus

Ezeigbo, H.I., and Ezeanyim, B.N.(1993): "Environmental Pollution from Coal Mining Activities in Enugu Area, Anambra State, Nigeria". Mine Water and the Environment, Vol. 12, annual issue. Pp 53-62.

Federal Republic of Nigeria Official Gazette (2007): No 24, Vol. 94, Lagos

Gatke, P. (2003): Future Management of Household Hazardous Waste in Petaling Jaya. A Preliminary Assessment. Dept of Technology, Environment and Social Studies. DUCED-MUCED I\&UA, Roskilde, University Centre.

Luna Raya Ma. Concepción (2002): Caracterización de los residuos sólidos domésticos sudiferenciación por estrato socioeconómico: Un estudio de caso para Tijuana, B. C. Master's Thesis in Integrated Environmental Administration, Colegio de la Frontera Norte y CICESE.Tijuana Baja California

Mamman, A.B.,Oyebanji, J.O. and Petters, S.W. (2000): Nigeria, A People United, A Future Assured. Vol. 2 millennium Ed. Gambumo Publishing Company Ltd. Calabar.

National Household Hazardous Waste Forum (1999): Good Practice Guide: the Definitive Guide to Best Practice in Household Hazardous Waste Management, Leeds, UK,NHHWF/SWAP.

Rosas Domínguez Anabell and Gutiérrez Palacios Constantino (1998) Estudio degeneraciónde residuos peligrosos domésticos en una zona habitacional. Universidad Nacional Autónoma de México Facultad de Ingeniería.

Slack, R. J, Gronow, J. R. and Voulvoulis,. N. (2004): "Hazardous components of household waste". Critical Reviews in Environmental Science and Technology 2004; 34: 419-45.

Slack, R. J, Gronow, J. R. and Voulvoulis, N. (2008a): "The Management of Household Hazardous Waste in the UK". Journal of Environmental Management. Elsevier Ltd. Article in Press.

Slack, R. J, Gronow, J. R. and Voulvoulis, N. (2008b): "Household Hazardous Waste in The UK: An Overview". Chartered Institution of Wastes Management (CWRM) :The Journal for Waste and Resource Management Professionals Vol 9(2) pp.69-73.. IWM Business Services Ltd.

Tammemagi, H. (1999): The Waste Crisis: Landfills, Incinerators and the Search for a Sustainable Future. New York: Oxford University Press.

Wilson Douglas .C.(1990) The Hazardousness of Cleaner Products in Household Refuse: Characteristics and Evaluation Journal March 1990, Volume 18, Issue No. 1 
